\title{
Perubahan asupan zat gizi tidak berpengaruh terhadap lama rawat inap pada pasien dewasa di RSUP Dr. Sardjito Yogyakarta
}

\author{
Effect of changes in nutrient intake on nutritional status and length of stay of adult patients in Dr. \\ Sardjito Hospital, Yogyakarta
}

Nurmala$^{1}$, Susetyowati ${ }^{2}$, R. Dwi Budiningsari ${ }^{2}$

\begin{abstract}
Backgrounds: Adequate nutrient intake for inpatients is much required in efforts to prevent declining nutrition status during hospitalization. Malnutrition may occur before hospitalization due to the disease or inadequate nutrient intake; however malnutrition may also occur during hospitalization. The result of a preliminary study shows that $75 \%$ of patients undergo declining nutrition status during hospitalization. Nutrition is an integral part of medication or recovery process and shortens length of stay.

Objectives: To identify effect of changes in nutrient intake to nutrition status and length of stay of adult inpatients.

Methods: The study was observational with prospective cohort approach using subject that got inadequate intake $(<80 \%)$ in the beginning of hospitalization as exposed group and those that got adequate intake $(\geq 80 \%)$ in the beginning of hospitalization as non exposed group. Assessment of inpatients was made after three days in hospital and then comparison was made to average intake prior to discharge.

Results: Changes in intake and nutritional status did not significantly $(p>0.05)$ affect length of stay of adult inpatients at internal medicine and neurology wards of Dr. Sardjito Hospital Yogyakarta. Nutrition therapy significantly $(p=0.04)$ affected change in nutritional status of inpatients with $R R=2.24$.

Conclusions: Changes in intake and nutritional status did not affect length of stay. Nutrition therapy affected as much as 2.24 times to changes in nutritional status of adult inpatients at internal medicine and neurology wards of Dr. Sardjito Hospital Yogyakarta.
\end{abstract}

KEYWORDS: length of stay, nutritional status, nutrient intake, nutrition therapy

\begin{abstract}
ABSTRAK
Latar belakang: Asupan zat gizi yang cukup bagi pasien sangat diperlukan untuk mencegah penurunan status gizi selama dirawat di rumah sakit. Malnutrisi juga dapat terjadi sejak sebelum masuk rumah sakit karena penyakit yang diderita maupun asupan zat gizi yang tidak adekuat, namun malnutrisi juga dapat terjadi setelah dirawat di rumah sakit. Hasil studi pendahuluan menunjukkan bahwa $75 \%$ pasien mengalami penurunan status gizi selama dirawat di rumah sakit. Terapi gizi merupakan bagian penting dari proses pengobatan dan pemulihan serta dapat mempersingkat lama rawat inap.

Tujuan: Untuk mengidentifikasi efek perubahan asupan zat gizi terhadap status gizi dan lama rawat inap pada pasien dewasa.

Metode: Penelitian ini merupakan penelitian observasional dengan desain kohort prospektif. Subjek dibagi menjadi 2 kelompok, yaitu kelompok yang memiliki asupan zat gizi tidak adekuat (<80\%) pada awal masa rawat inap di rumah sakit sebagai kelompok terpapar dan kelompok yang memiliki asupan zat gizi adekuat ( $\geq 80 \%$ ) pada awal masa rawat inap di rumah sakit sebagai kelompok tidak terpapar. Pengukuran asupan makan dilakukan setelah pasien tiga hari dirawat di rumah sakit untuk selanjutnya dibandingkan dengan rata-rata pengukuran asupan pasien sebelum pulang.
\end{abstract}

\footnotetext{
${ }^{1}$ Rumah Sakit S dr. H. M. Rabain Hospital, Muara Enim

${ }^{2}$ Pasca Sarjana Gizi dan Kesehatan Fakultas Kedokteran Universitas Gadjah Mada, Jl. Farmako, Sekip Utara Yogyakarta 55281
} 


\begin{abstract}
Hasil: Perubahan pada asupan dan status gizi tidak berpengaruh secara signifikan terhadap lama rawat inap pasien dewasa di bangsal penyakit dalam dan saraf RSUP Dr. Sardjito. Terapi gizi secara signifikan mempengaruhi perubahan status gizi pasien dengan $R R=2,24$.

Kesimpulan: Perubahan pada asupan dan status gizi tidak berpengaruh secara signifikan terhadap lama rawat inap. Terapi gizi yang diberikan dapat memiliki pengaruh sebesar 2,24 kali untuk mengubah status gizi pasien.
\end{abstract}

KATA KUNCI: lama rawat inap, status gizi, asupan zat gizi, terapi gizi

\section{PENDAHULUAN}

Rumah sakit sebagai sarana kesehatan yang memberikan pelayanan kesehatan kepada masyarakat bertujuan untuk mengobati penderitanya (upaya kuratif) dengan tidak mengabaikan peran lainnya untuk melakukan upaya promotif, preventif dan rehabilitatif.Angka malnutrisi di rumah sakit cukup tinggi dan merata, baik rumah sakit kabupaten maupun rumah sakit universitas atau pendidikan (1). Malnutrisi dapat timbul sebelum dirawat karena penyakitnya atau masukan zat gizi yang tidak cukup, namun malnutrisi dapat juga timbul selama dirawat inap.Malnutrisi terjadi antara $40-60 \%$ dari pasien rawat inap dengan penyakit akut, yang awalnya datang tanpa masalah gizi dan kemudian terjadi penurunan status gizi dalam waktu tiga minggu secara perlahan (2).

Faktor yang mempengaruhi terjadinya malnutrisi di rumah sakit, yaitu masih kurangnya koordinasi seperti monitoring antropometri yang meliputi pengukuran dan pencatatan berat badan serta tinggi badan, penyimpangan tanggung jawab petugas gizi dalam hal tata laksana gizi, pengamatan asupan makanan belum dilakukan secara kontinyu, sering memuasakan pasien untuk tes diagnostik, sarana dan keterampilan yang belum memadai sehingga perhatian dalam pemberian makanan masih kurang, serta belum ada pedoman penatalaksanaan asuhan gizi (3).

Tujuan penilaian status gizi pasien di rumah sakit yaitu untuk menentukan status gizi pasien secara akurat, menentukan hubungan perubahan status gizi dengan malnutrisi secara klinis dan memonitor selama mendapatkan terapi gizi. Terapi gizi yang tepat akan meningkatkan indikator klinis dan biokimia sehingga pasien mempunyai ketahanan tubuh yang baik dan risiko komplikasi yang rendah
(4). Hasil penelitian multisenter di Amerika Latin yang melibatkan 9348 pasien diperoleh hasil bahwa terdapat $50,2 \%$ pasien malnutrisi (5).

Penelitian ini bertujuan untuk mengidentifikasi pengaruh perubahan asupan zat gizi terhadap perubahan status gizi dan lama rawat inap pasien di bangsal penyakit dalam dan saraf RSUP Dr. Sardjito Yogyakarta. Beberapa variabel lain seperti ada tidaknya jenis penyakit, terapi diet dan tindakan medis juga akan dilihat pengaruhnya terhadap perubahan status gizi dan lama rawat inap pasien dewasa.

\section{BAHAN DAN METODE}

Penelitian berlokasi di Rumah Sakit Umum Pusat (RSUP) Dr. Sardjito Yogyakarta yang merupakan rumah sakit pendidikan bagi Fakultas Kedokteran Universitas Gadjah Mada dan pusat rujukan untuk wilayah DIY, Jawa Tengah dan sekitarnya. Desain penelitian menggunakan studi observasional dengan rancangan studi kohort prospektif.Subjek penelitian dibagi menjadi 2 kelompok yaitu kelompok yang memiliki asupan tidak cukup ( $<80 \%$ ) pada awal masa rawat inap di rumah sakit sebagai kelompok terpapar (exposed) dan kelompok yang memiliki asupan cukup $(\geq 80 \%)$ pada awal masa rawat inap di rumah sakit sebagai kelompok tidak terpapar (non exposed), kemudian diukur status gizi dan lama rawat inap sebagai efek (outcome).

Penelitian ini merupakan bagian dari penelitian multicentre tentang nutritional status and hospital outcomes yang dilaksanakan di ruang rawat inap bangsal penyakit dalam dan saraf. Waktu pengumpulan data penelitian dimulai pada bulan Agustus dan berakhir bulan Desember 2009.

Subjek penelitian diambil secara purposive sampling, dengan kriteria inklusi: pasien bersedia ikut dalam penelitian ini dengan menandatangani 
informed consent, pasien berusia lebih dari atau sama dengan 18 tahun, dirawat di bangsal penyakit dalam atau saraf minimal 3 hari, dapat diukur berat badan dan tinggi badan, serta kesadaran kompos mentis. Kriteria eksklusi adalah pasien yang pindah kelas perawatan atau bangsal. Berdasarkan perhitungan besar sampel, diperoleh sampel minimal adalah 70 orang untuk setiap kelompok, sehingga total yang dibutuhkan minimal adalah 140 orang. Pada penelitian ini dapat diperoleh sampel sebanyak 255 orang (103 orang pada kelompok tidak terpapar dan 152 orang pada kelompok terpapar).

Perubahan asupan zat gizi dikategorikan menjadi dua, yaitu meningkat dan menurun. Asupan zat gizi dikategorikan meningkat apabila terjadi perubahan antara kategori asupan zat gizi di awal dan di akhir yaitu dari kategori tidak cukup menjadi cukup atau dari cukup tetap menjadi cukup. Sementara asupan zat gizi dikategorikan menurun apabila terjadi perubahan kategori asupan zat gizi awal dan akhir yaitu dari kategori cukup menjadi tidak cukup atau dari tidak cukup tetap menjadi tidak cukup.

Asupan zat gizi awal ditentukan berdasarkan rata-rata asupan makan responden selama 3 hari pertama dirawat di rumah sakit, dan asupan zat gizi akhir ditentukan berdasarkan rata-rata asupan makan pada hari ke-4 hingga responden pulang. Asupan zat gizi tersebut selanjutnya dikategorikan menjadi cukup bila memenuhi $\geq 80 \%$ AKG dan tidak cukup bila hanya memenuhi $<80 \%$ AKG.

\section{HASIL}

Tabel 1 menunjukkan bahwa persentase pasien yang mengalami penurunan asupan zat gizi (asupan awal tergolong cukup sementara asupan akhir tergolong tidak cukup) lebih besar dibandingkan persentase pasien yang mengalami peningkatan asupan zat gizi (asupan awal tergolong tidak cukup sementara asupan akhir tergolong cukup), yaitu $11,65 \%$ dibandingkan dengan $7,24 \%$.

Tabel 2 menunjukkan bahwa persentase pasien yang mengalami peningkatan status gizi (status gizi awal tergolong kurang dan status gizi akhir menjadi baik) lebih tinggi dibandingkan dengan persentase pasien yang mengalami penurunan status gizi (status gizi awal tergolong baik namun status gizi akhir menjadi kurang), yaitu $29,73 \%$ dibandingkan dengan $16,02 \%$.

Karakteristik subjek menurut perubahan asupan zat gizi pada Tabel 3 menunjukkan bahwa persentase penurunan asupan zat gizi lebih besar pada kelompok responden dengan usia dewasa $(60 \%)$, tingkat pendidikan rendah $(60,3 \%)$, bekerja $(62,4 \%)$, dirawat di bangsal penyakit dalam $(61,9 \%)$, dan kelas perawatan di kelas $3(62,1 \%)$. Sementara berdasarkan jenis kelamin tidak terdapat perbedaan persentase penurunan asupan zat gizi. Uji chi-

Tabel 1. Distribusi asupan zat gizi awal dan perubahan asupan zat gizi

\begin{tabular}{lccccccc}
\hline \multirow{2}{*}{ Asupan zat gizi awal } & \multicolumn{3}{c}{ Perubahan asupan zat gizi } & \multicolumn{3}{c}{ Total } \\
\cline { 2 - 5 } & \multicolumn{2}{c}{ Meningkat } & \multicolumn{2}{c}{ Menurun } & \multirow{2}{*}{$\mathbf{n}$} & \multirow{2}{*}{$\%$} \\
\cline { 2 - 5 } & $\mathbf{n}$ & $\%$ & $\mathbf{n}$ & $\%$ & & 103 & 100 \\
\hline$\geq 80 \%$ AKG (Cukup) & 91 & 88,35 & 12 & 11,65 & & 152 & 100 \\
$<80 \%$ AKG (Tidak cukup) & 11 & 7,24 & 141 & 92,76 & & 100 \\
Jumlah & 102 & 40 & 153 & 60 & 255 & 100 \\
\hline
\end{tabular}

Tabel 2. Distribusi status gizi awal masuk rumah sakit dan perubahan status gizi saat pulang dari rumah sakit

\begin{tabular}{lccccccc}
\hline \multirow{2}{*}{ Status gizi awal } & \multicolumn{3}{c}{ Perubahan status gizi } & \multicolumn{3}{c}{ Total } \\
\cline { 2 - 6 } & \multicolumn{2}{c}{ Meningkat } & \multicolumn{2}{c}{ Menurun } & \multirow{2}{*}{$\mathbf{n}$} & \multirow{2}{*}{$\%$} \\
\cline { 2 - 6 } & $\mathbf{n}$ & $\mathbf{0}$ & $\mathbf{n}$ & $\mathbf{\%}$ & & 161 & 100 \\
\hline Baik (IMT $\geq 18,5)$ & 152 & 83,98 & 29 & 16,02 & & 181 & 100 \\
Kurang (IMT $<18,5)$ & 22 & 29,73 & 52 & 70,27 & 74 & 100 \\
Jumlah & 174 & 68,24 & 81 & 31,76 & 255 & \\
\hline
\end{tabular}


Tabel 3. Karakteristik subjek menurut perubahan asupan zat gizi

\begin{tabular}{|c|c|c|c|c|c|c|c|c|}
\hline \multirow{3}{*}{ Karakteristik } & \multicolumn{4}{|c|}{ Perubahan asupan zat gizi } & \multirow{3}{*}{$\Sigma(n)$} & \multirow[b]{3}{*}{$(\%)$} & \multirow{3}{*}{$\chi^{2}$} & \multirow{3}{*}{$\mathbf{p}$} \\
\hline & \multicolumn{2}{|c|}{ Menurun } & \multicolumn{2}{|c|}{ Meningkat } & & & & \\
\hline & (n) & $(\%)$ & (n) & $(\%)$ & & & & \\
\hline \multicolumn{9}{|l|}{ Kelompok usia } \\
\hline Lansia & 28 & 57,1 & 21 & 42,9 & 49 & 100 & 0,94 & 0,78 \\
\hline Dewasa & 125 & 60,0 & 81 & 39,3 & 206 & 100 & & \\
\hline \multicolumn{9}{|l|}{ Jenis kelamin } \\
\hline Laki-laki & 54 & 60,0 & 36 & 40,0 & 90 & 100 & 1 & 1,00 \\
\hline Perempuan & 99 & 60,0 & 66 & 40,0 & 165 & 100 & & \\
\hline \multicolumn{9}{|l|}{ Tingkat pendidikan } \\
\hline Rendah ( $\leq$ SLTP) & 79 & 60,3 & 52 & 39,7 & 131 & 100 & 1,01 & 1,00 \\
\hline Tinggi ( $\geq$ SLTA) & 74 & 59,7 & 50 & 40,3 & 124 & 100 & & \\
\hline \multicolumn{9}{|l|}{ Pekerjaan } \\
\hline Tidak bekerja & 65 & 57,0 & 49 & 43,0 & 114 & 100 & 0,91 & 0,46 \\
\hline Bekerja & 88 & 62,4 & 53 & 37,6 & 141 & 100 & & \\
\hline \multicolumn{9}{|l|}{ Bangsal } \\
\hline Penyakit dalam & 133 & 61,9 & 82 & 38,1 & 215 & 100 & 1,24 & 0,22 \\
\hline Penyakit saraf & 20 & 50,0 & 20 & 50,0 & 40 & 100 & & \\
\hline \multicolumn{9}{|l|}{ Kelas perawatan } \\
\hline Kelas 3 & 82 & 62,1 & 50 & 37,9 & 132 & 100 & 1,08 & 0,56 \\
\hline Kelas 1 \& 2 & 71 & 57,7 & 52 & 42,3 & 123 & 100 & & \\
\hline Jumlah & 153 & - & 102 & - & 255 & - & - & - \\
\hline
\end{tabular}

square tidak menunjukkan hubungan signifikan antara karakteristik subjek tersebut dengan perubahan asupan zat gizi $(p>0,05)$.

Tabel 4 menunjukkan hasil uji statistik terhadap variabel-variabel luar dengan perubahan asupan zat gizi. Secara keseluruhan, variabelvariabel luar tersebut menunjukkan hubungan yang tidak signifikan dengan perubahan asupan zat gizi $(p>0,05)$. Selanjutnya, analisis hubungan antara variabel luar dan perubahan asupan zat gizi dengan perubahan status gizi ditampilkan dalam Tabel 5. Hasil uji statistik menunjukkan bahwa variabel terapi gizi berhubungan secara signifikan dengan perubahan status gizi $(p=0,04)$. Persentase peningkatan status gizi terjadi lebih tinggi pada kelompok responden yang memperoleh terapi diet biasa $(80,4 \%)$ dibandingkan dengan kelompok responden yang memperoleh terapi diet khusus $(64,8 \%)$. Relative risk sebesar 0,56 menunjukkan bahwa terapi diet biasa merupakan faktor protektif terhadap penurunan status gizi pasien dewasa di rumah sakit. Sementara variabel perubahan asupan zat gizi serta variabel luar lainnya tidak berhubungan secara signifikan dengan perubahan status gizi $(p>0,05)$.

Berdasarkan Tabel 6, diketahui bahwa variabel terapi medis memiliki hubungan yang signifikan terhadap lama rawat inap pasien di rumah sakit $(p=0,00)$. Persentase lama rawat inap yang panjang ( $>7$ hari) $20 \%$ lebih tinggi pada kelompok responden yang mendapatkan terapi medis berupa hemodialisa atau terpasang oksigen, dibandingkan dengan kelompok responden yang tanpa terapi medis. Sementara variabel utama dalam penelitian ini, yaitu perubahan asupan makan dan perubahan status gizi tidak memiliki hubungan yang bermakna secara statistik dengan lama rawat inap di rumah sakit. Variabel jenis penyakit dan terapi gizi juga tidak berhubungan secara signifikan terhadap lama rawat inap pasien di rumah sakit.

Dari Tabel 7 dapat diasumsikan bahwa kelas perawatan berhungan signifikan dengan perubahan status gizi ( $R R=0,38,95 \% \mathrm{Cl}: 0,218-0,672)$. Sementara variabel lainnya tidak menunjukkan hubungan yang signifikan. 
Tabel 4. Analisis bivariat variabel luar terhadap perubahan asupan zat gizi

\begin{tabular}{|c|c|c|c|c|c|c|c|c|}
\hline \multirow{3}{*}{ Variabel } & \multicolumn{4}{|c|}{ Perubahan asupan zat gizi } & \multirow{3}{*}{ Total } & \multirow{3}{*}{$(\%)$} & \multirow{3}{*}{$\begin{array}{c}\mathrm{RR} \\
(95 \% \mathrm{Cl})\end{array}$} & \multirow{3}{*}{$\mathbf{p}$} \\
\hline & \multicolumn{2}{|c|}{ Menurun } & \multicolumn{2}{|c|}{ Meningkat } & & & & \\
\hline & (n) & $(\%)$ & (n) & $(\%)$ & & & & \\
\hline \multicolumn{9}{|l|}{ Jenis penyakit } \\
\hline Gastro & 98 & 57,0 & 74 & 43,0 & 172 & 100 & 0,86 & 0,20 \\
\hline Non gastro & 55 & 66,3 & 28 & 33,7 & 83 & 100 & $(0,70-1,05)$ & \\
\hline \multicolumn{9}{|l|}{ Terapi gizi } \\
\hline Biasa & 37 & 66,1 & 19 & 33,9 & 56 & 100 & 1,13 & 0,37 \\
\hline Khusus & 116 & 58,3 & 83 & 41,7 & 199 & 100 & $(1,00-1,22)$ & \\
\hline \multicolumn{9}{|l|}{ Tindakan medis } \\
\hline $\mathrm{Ya}^{*}$ & 96 & 60,4 & 63 & 39,6 & 159 & 100 & 0,98 & 0,98 \\
\hline Tidak & 57 & 59,4 & 39 & 40,6 & 96 & 100 & $(0,80-1,21)$ & \\
\hline Jumlah & 153 & - & 102 & - & 255 & - & - & - \\
\hline
\end{tabular}

*Hemodialisis, pemasangan oksigen.

Tabel 5. Analisis bivariat variabel luar dan perubahan asupan zat gizi terhadap perubahan status gizi

\begin{tabular}{|c|c|c|c|c|c|c|c|c|}
\hline \multirow{3}{*}{ Variabel } & \multicolumn{4}{|c|}{ Perubahan status gizi } & \multirow{3}{*}{ Total } & \multirow{3}{*}{$(\%)$} & \multirow{3}{*}{$\begin{array}{c}\mathrm{RR} \\
(95 \% \mathrm{Cl})\end{array}$} & \multirow{3}{*}{$\mathbf{p}$} \\
\hline & \multicolumn{2}{|c|}{ Menurun } & \multicolumn{2}{|c|}{ Meningkat } & & & & \\
\hline & (n) & $(\%)$ & (n) & $(\%)$ & & & & \\
\hline \multicolumn{9}{|l|}{ Jenis penyakit } \\
\hline Gastro & 55 & 32,0 & 117 & 68,0 & 172 & 100 & 1,02 & 1,00 \\
\hline Non gastro & 26 & 31,3 & 57 & 68,7 & 83 & 100 & $(0,70-1,50$ & \\
\hline \multicolumn{9}{|l|}{ Terapi gizi } \\
\hline Biasa & 11 & 17,8 & 45 & 80,4 & 56 & 100 & 0,56 & $0,04^{*}$ \\
\hline Khusus & 70 & 35,2 & 129 & 64,8 & 199 & 100 & $(0,46-0,95)$ & \\
\hline \multicolumn{9}{|l|}{ Tindakan medis } \\
\hline $\mathrm{Ya}^{* *}$ & 27 & 28,1 & 69 & 71,9 & 96 & 100 & 0,83 & 0,41 \\
\hline Tidak & 54 & 34,0 & 105 & 66,0 & 159 & 100 & $(0,78-1,09)$ & \\
\hline \multicolumn{9}{|c|}{ Perubahan asupan zat gizi } \\
\hline Menurun & 46 & 30,1 & 107 & 69,9 & 153 & 100 & 0,88 & 0,56 \\
\hline Meningkat & 35 & 34,3 & 67 & 65,7 & 102 & 100 & $(0,89-1,27)$ & \\
\hline Jumlah & 174 & 100 & 81 & 100 & 255 & - & - & - \\
\hline
\end{tabular}

* Signifikan $(p<0,05)$

** Hemodialisis, pemasangan oxygen

Hasil uji regresi logistik menunjukkan bahwa variabel jenis kelamin, bangsal, kelas perawatan dan tindakan medis mempunyai pengaruh terhadap perubahan status gizi dengan nilai $p<0,25$, namun variabel kelas perawatan yang paling dominan berpengaruh terhadap lama rawat. Subjek yang di rawat pada kelas 1 dan 2 kemungkinan akan mengalami lama rawat inap lebih panjang sebesar 1,46 kali dibandingkan dengan subjek yang di rawat pada kelas 3 .

Setelah dilakukan uji regresi logistik kedua kalinya menunjukkan bahwa variabel jenis kelamin yang paling dominan berpengaruh terhadap lama rawat. Subjek dengan jenis kelamin laki - laki lebih panjang rawat inapnya sebesar 0,52 kali dibandingkan dengan jenis kelamin perempuan.

\section{BAHASAN}

Hasil penelitian ini menunjukkan bahwa perubahan asupan gizi tidak memberikan pengaruh terhadap perubahan status gizi. Hal ini tidak sejalan dengan penelitian sebelumnya yang menunjukkan bahwa pasien dengan status gizi kurang selama dirawat akan mempengaruhi lama hari rawat 6,3 kali lebih panjang dan berisiko 3,3 kali lebih tinggi untuk mengeluarkan lebih banyak biaya perawatan dibandingkan pasien yang memiliki 
Tabel 6. Analisis bivariat variabel luar, perubahan asupan zat gizi dan perubahan status gizi terhadap lama rawat inap

\begin{tabular}{|c|c|c|c|c|c|c|c|c|}
\hline \multirow[b]{2}{*}{ Variabel } & \multicolumn{2}{|c|}{$\begin{array}{c}\text { Lama rawat } \\
\text { panjang (>7 hari) }\end{array}$} & \multicolumn{2}{|c|}{$\begin{array}{l}\text { Lama rawat pendek } \\
\qquad(\leq 7 \text { hari) }\end{array}$} & \multirow[b]{2}{*}{ Total } & \multirow[b]{2}{*}{ (\%) } & \multirow[t]{2}{*}{$\begin{array}{c}\text { RR } \\
(95 \% \mathrm{Cl})\end{array}$} & \multirow[t]{2}{*}{ p } \\
\hline & (n) & $(\%)$ & (n) & $(\%)$ & & & & \\
\hline \multicolumn{9}{|l|}{ Jenis penyakit } \\
\hline Gastro & 101 & 58,7 & 71 & 41,3 & 172 & 100 & \multirow{2}{*}{$\begin{array}{c}0,97 \\
(0,78-1,21)\end{array}$} & \multirow[t]{2}{*}{0,92} \\
\hline Non gastro & 50 & 60,2 & 33 & 39,8 & 83 & 100 & & \\
\hline \multicolumn{9}{|l|}{ Terapi gizi } \\
\hline Biasa & 34 & 60,7 & 22 & 39,3 & 56 & 100 & \multirow{2}{*}{$\begin{array}{c}1,03 \\
(0,71-1,49)\end{array}$} & \multirow[t]{2}{*}{0,92} \\
\hline Khusus & 117 & 58,8 & 82 & 41,2 & 199 & 100 & & \\
\hline \multicolumn{9}{|c|}{ Tindakan medis } \\
\hline$Y^{* *}$ & 69 & 71,9 & 27 & 28,1 & 96 & 100 & \multirow{2}{*}{$\begin{array}{c}0,72 \\
(0,59-0.87)\end{array}$} & \multirow[t]{2}{*}{$0,00^{*}$} \\
\hline Tidak & 83 & 51,6 & 77 & 48,4 & 159 & 100 & & \\
\hline \multicolumn{9}{|c|}{ Perubahan asupan zat gizi } \\
\hline Menurun & 46 & 30,1 & 107 & 69,9 & 153 & 100 & \multirow{2}{*}{$\begin{array}{c}1,07 \\
(0,89-1,27)\end{array}$} & \multirow[t]{2}{*}{0,56} \\
\hline Meningkat & 35 & 34,3 & 67 & 65,7 & 102 & 100 & & \\
\hline \multicolumn{9}{|c|}{ Perubahan status gizi } \\
\hline Menurun & 46 & 62,2 & 28 & 37,8 & 74 & 100 & \multirow{3}{*}{$\begin{array}{c}0,84 \\
(0,48-1,46)\end{array}$} & \multirow[t]{2}{*}{0,57} \\
\hline Meningkat & 105 & 58,0 & 76 & 42,0 & 181 & 100 & & \\
\hline Jumlah & 151 & - & 104 & - & 255 & - & & - \\
\hline
\end{tabular}

* Signifikan $(p<0,05)$

** Hemodialisis, pemasangan oxygen

Tabel 7. Analisis multivariat (variabel terikat : perubahan status gizi)

\begin{tabular}{lcccc}
\hline \multicolumn{1}{c}{ Variabel } & $\boldsymbol{\beta}$ & $\mathbf{p}$ & $\mathbf{E x p ( B )}$ & $\mathbf{9 5 \%} \mathbf{C l}$ \\
\hline Kelompok usia & 0,051 & 0,86 & 1,05 & $0,602-1,839$ \\
Jenis kelamin & 0,403 & 0,19 & 0,67 & $0,365-1,226$ \\
Kelas perawatan & 0,960 & 0,00 & 0,38 & $0,218-0,672$ \\
Terapi gizi & 0,804 & 0,37 & 2,24 & $1,051-4,752$ \\
\hline
\end{tabular}

Tabel 8. Analisis multivariat (variabel terikat : lama rawat inap)

\begin{tabular}{lcccc}
\hline Model Variabel & $\mathbf{B}$ & $\mathbf{p}$ & $\mathbf{x p}(\mathbf{B})$ & $\mathbf{9 5 \%} \mathbf{C l}$ \\
\hline Jenis kelamin & 0,664 & 0,025 & 0,515 & $0,288-0,920$ \\
Bangsal & 1,013 & 0,016 & 0,363 & $0,159-0,831$ \\
Kelas perawatan & 0,383 & 0,170 & 1,466 & $0,849-2,533$ \\
$\quad$ Tindakan medis & 0,932 & 0,001 & 0,394 & $0,223-0,695$ \\
Jenis kelamin & 0,664 & 0,025 & 0,515 & $0,288-0,920$ \\
Bangsal & 1,013 & 0,016 & 0,363 & $0,159-0,831$ \\
Tindakan medis & 0,932 & 0,001 & 0,394 & $0,223-0,695$ \\
\hline
\end{tabular}

asupan protein dan gizi yang baik (6). Penelitian lain juga mengungkapkan bahwa pada pasien yang diberikan diet modifikasi mempunyai hari rawat yang lebih pendek bila dibandingkan dengan yang diberikan diet biasa. Rata-rata hari rawat tersebut adalah 3 hari untuk yang diberi diet modifikasi dan 5 hari untuk yang diberi diet makanan biasa (7).

Hasil penelitian ini juga menunjukkan bahwa perubahan asupan gizi tidak memberikan pengaruh terhadap lama rawat inap. Hasil ini sejalan dengan penelitian sebelumnya yang dilakukan terhadap 23 subjek intervensi tinggi kalori tinggi protein (TKTP) dan 21 subjek kontrol yang diberikan susu tinggi protein. Pada awal penelitian status gizi dua kelompok tersebut sama. Setelah dilakukan intervensi dengan pemberian diet TKTP, ditemukan bahwa tidak terdapat hubungan yang signifikan terhadap perubahan status gizi antara dua kelompok 
tersebut dan rata-rata lama rawat inap (8). Namun demikian, hasil ini tidak sesuai dengan penelitian lain yang menemukan bahwa asupan protein yang rendah merupakan faktor risiko makin lamanya hari rawat. Asupan protein yang kurang pada pasien rawat inap, disertai dengan status gizi yang kurang, berisiko 1,83 kali untuk mengalami perawatan yang lebih lama dibandingkan dengan pasien yang memiliki asupan protein yang cukup (9).

Ketidaksesuaian ini kemungkinan disebabkan lama rawat inap tidak hanya dipengaruhi oleh perubahan asupan dan perubahan status gizi, tetapi juga dapat dipengaruhi oleh mikronutrien dan zat gizi lain. Sebuah penelitian bertujuan untuk membandingkan antara pasien bedah dan komplikasi yang diberikan antioksidan ( $\alpha$ tokoferol dan vitamin C) dan yang hanya mendapatkan makanan standar. Penelitian tersebut menemukan bahwa pada kelompok yang diberi antioksidan mempunyai durasi rawat inap di ICU yang lebih pendek. Faktor lain yang menyebabkan ketidaksesuaian hasil penelitian ini, dapat juga disebabkan oleh perbedaan jenis penyakit (10). Penelitian sebelumnya menyatakan bahwa lama rawat inap berhubungan dengan jenis penyakit. Dua kelompok pasien yaitu dengan penyakit ginecological dan neoplasma, mempunyai lawa rawat inap yang berbeda (11).

Antara asupan energi terhadap peningkatan status gizi dan lama rawat inap secara fisiologis membutuhkan energi sebagai sumber tenaga bagi penyembuhan selama dirawat di rumah sakit, peneliti menyarankan pengukuran asupan energi dilakukan pada saat pasien datang atau dirawat agar diketahui kebutuhan asupan energi yang ideal bagi pasien untuk mempercepat proses penyembuhan sehingga dapat mengurangi beban keluarga secara ekonomis dan dapat mengurangi lama rawat inap.

Berat badan merupakan salah satu ukuran tubuh yang paling banyak digunakan memberikan gambaran massa jaringan, termasuk cairan tubuh. Berat badan sangat mudah dipengaruhi oleh keadaan mendadak, seperti terserang infeksi atau diare, konsumsi makanan yang menurun. Sebagai indikator status gizi, berat badan dalam bentuk indeks berat badan menurut umur (BB/U) dan berat badan menurut tinggi badan (BB/TB) menggambarkan keadaan status gizi sekarang.

Pengukuran berat badan setiap hari (di rumah sakit) atau setiap minggu pada orang yang tidak sakit merupakan parameter yang objektif, tetapi yang menjadi kendala adalah tidak semua pasien yang dirawat dapat dilakukan penimbangan berat badan dengan timbangan biasa karena banyak pasien yang rata-rata tidak bisa berdiri. Padahal data berat badan pasien sangat diperlukan. Alternatif lain adalah dengan tempat tidur pasien yang memiliki pengukuran berat badan (bed scale).

Hasil penelitian ini sejalan dengan penelitian sebelumnya yang menyimpulkan tidak ada perbedaan signifikan variabel penelitian berat badan antara pria dan wanita setelah 5 hari dirawat $(p=0,09$ dan $p=0,12$ ). Hal ini dapat disebabkan penambahan berat badan rerata antara wanita dan pria sama. Berat badan pria bertambah seiring peningkatan lemak khususnya pada bagian perut, sedangkan penelitian lain menyimpulkan bahwa wanita baik di negara maju maupun di negara berkembang mempunyai lemak tubuh (fat mass) lebih besar dari pria, karena untuk menutupi kebutuhan reproduktif yang meningkat khusus pada waktu hamil dan pada waktu memberikan ASI (12).

Variabel ada atau tidaknya tindakan medis (operasi, kemo terapi) berpengaruh terhadap peningkatan status gizi subjek penelitian sehubungan masa rehabilitasi dan proses penyembuhan yang dibutuhkan oleh tubuh untuk proses perbaikan sel-sel yang mati dan berhubungan erat terhadap lama rawat inap. Hasil penelitian ini sejalan dengan penelitian sebelumnya yang meneliti hubungan status gizi awal dengan status gizi pada saat pulang dan lama rawat inap pasien dewasa yang dilakukan tindakan medis di ruang rawat inap rumah sakit (9). Kesimpulan dari penelitian tersebut adalah terdapat hubungan antara adanya tindakan medis terhadap status gizi dan lama rawat inap.

Kelas perawatan merupakan salah satu faktor yang dapat mempengaruhi perubahan status gizi pasien rawat inap secara tidak langsung. Pada umumnya, malnutrisi dapat timbul sejak sebelum dirawat di rumah sakit yang disebabkan penyakitnya atau asupan zat gizi yang tidak cukup, namun tak 
jarang pula malnutirisi ini timbul selama dirawat inap. Hasil studi pendahuluan menunjukkan bahwa kurang lebih $75 \%$ penderita yang dirawat inap menurun status gizinya dibandingkan dengan status gizi saat mulai dirawat. Hal ini membuktikan bahwa penurunan status gizi dapat terjadi selama dirawat inap. Penurunan status gizi dapat menyebabkan angka mortalitas naik dan memperpanjang lama hari rawat (13). Data menunjukkan sekitar $48 \%$ pasien baru masuk di rawat inap menderita kurang gizi dan setelah dirawat inap dua minggu prevalensinya akan meningkat menjadi $69 \%$ (14).

Hasil penelitian ini menujukkan bahwa subjek yang dirawat di kelas 1 dan 2 mengalami penurunan status gizi lebih tinggi dibandingkan dengan subjek yang dirawat di kelas 3 . Hal ini disebabkan karena subjek yang dirawat di kelas 1 dan 2 tidak terlepas dari permasalahan yang dihadapi oleh penderita selama dirawat termasuk faktor psikologis dan stres juga berpengaruh terhadap daya terima makanan. Permasalahan tersebut akan dapat mengganggu dalam mempertahankan kecukupan gizi dan menimbulkan penurunan berat badan yang berakibat pada penyembuhan sehingga berdampak pada perubahan status gizi serta memperpanjang lama hari rawat.

Kelas perawatan dapat mempengaruhi persepsi pasien terhadap makanan yang disajikan sehingga berdampak pula pada penerimaan pasien terhadap makanan dan akhirnya mempengaruhi asupan makan pasien (9). Hasil penelitian sebelumnya menemukan bahwa bagi subjek lansia pada kelompok neoplasma berisiko untuk lama rawat panjang $(p<0,0008)$ dibandingkan dengan subjek dewasa pada kelompok gynecological, variabel jenis kelamin laki-laki mempunyai risiko lama rawat inap panjang dan tidak menunjukkan hasil yang bermakna antara kelompok ginecologycal dan neoplasma $(p<0,001)$ dan pada kelompok neoplasma menunjukkan ada hubungan bermakna antara peningkatan perubahan status gizi dengan lama rawat inap panjang $(p<0,001)(15)$.

Selain berpengaruh pada perubahan status gizi variabel kelas perawatan juga berpengaruh terhadap lama rawat inap, subjek yang di rawat di kelas 3 banyak yang menggunakan sumber pembiayaan dijamin oleh pihak ketiga dalam hal ini jamkesmas. Jamkesmas menyediakan bantuan dana dalam bentuk paket sesuai dengan ketentuan yang berlaku. Subjek terkadang harus pulang dengan status kesehatan yang belum optimal karena terbatasnya jaminan tersebut. Hal ini merupakan salah satu faktor yang membuat subjek yang di rawat di kelas 3 hari rawatnya lebih pendek dibandingkan dengan subjek yang di rawat di kelas 1 dan 2. Faktor psikologis dan stres merupakan faktor lain yang dapat mempengaruhi kenyamanan subjek sehingga tak jarang pula ada di antara subjek yang pulang dengan permintaan sendiri dengan pertimbangan biaya rawat dan mengharuskan subjek terpaksa dibawa pulang oleh pihak keluarga sehingga menyebabkan pengobatan dan perawatan belum sampai tuntas dan mempercepat hari rawat.

Berdasarkan terapi gizi secara teoritis, dari sisi daya terima pasien yang mendapat terapi gizi makanan biasa lebih tinggi asupannya dibandingkan pasien yang memperoleh makanan dengan diet khusus. Diet khusus kurang bisa diterima oleh pasien karena tekstur, rasanya yang kurang, porsi yang tidak sama dengan kebiasaan pola makan di rumah. Hal tersebut dapat berpengaruh pada konsumsi pasien dan akan berdampak terhadap perubahan status gizi sehingga akan memperpanjang lama hari rawat. Subjek yang mendapatkan terapi gizi biasa lama rawatnya lebih panjang dibandingkan pasien yang mendapatkan terapi gizi khusus. Hal ini disebabkan tidak sesuainya kebutuhan dan kecukupan zat gizi yang adekuat bagi seseorang pasien.

Hasil penelitian ini menunjukkan terdapat hubungan signifikan antara terapi gizi dengan peningkatan status gizi maupun lama rawat inap disebabkan proporsi subjek penelitian yang mendapatkan jenis diet khusus lebih besar dibanding subjek dengan makanan biasa yaitu ( 8 orang/7,1\%) sehingga tidak mempengaruhi terhadap analisis yang dilakukan oleh peneliti.

\section{KESIMPULAN DAN SARAN}

Tidak ada pengaruh perubahan asupan zat gizi terhadap perubahan status gizi dan lama rawat 
inap. Kelas perawatan merupakan variabel risiko dominan terhadap lama rawat inap. Disarankan bagi pasien yang mengalami tindakan medis diperlukan pemantauan status gizi secara intensif dari pihak rumah sakit, karena telah terbukti mempengaruhi peningkatan status gizi dan lama hari perawatan pasien. Perlu penelitian lebih lanjut tentang hubungan dan perbedaan asupan energi, protein, berat badan pasien serta pengukuran IMT sebelum, selama dan setelah dirawat di rumah sakit pada pasien yang mempunyai gangguan gastroenterologi, sehingga dapat diperoleh gambaran tentang bahanbahan makanan apa saja yang membuat perbedaan status gizi pasien yang dirawat.

\section{RUJUKAN}

1. Soegih, R. Pola penanganan kasus gizi di puskesmas dan rumah sakit. Kapita selekta nutrisi klinik. Jakarta: Perhimpunan Nutrisi Enteral dan Parenteral Indonesia. 1998.

2. Braunchweig, C., Gomez, S., \& Sheeam, P. Impact of declines in nutritional status on outcomes in adult patients hospitalized for more than 7 days. Journal of the American Dietation Association, $100: 1316$ - 1324. 2000.

3. Oktoruddin. Faktor-faktor yang mempengaruhi status gizi pasien selama dirawat di bagian penyakit dalam RSUPCN-CM. Media Dietetik. Jakarta : Asosiasi Dietesien Indonesia. 2002.

4. Gibson, R.S. Principles of nutritional assessment. New York : Oxford University Press. 2005.

5. Correia, M.I.T.D. and Campos, A.C.L. (2003) Prevalence of hospital malnutrition in latin America: the multicentre ELAN study. Nutrition, 19:823-5.

6. Budiningsari, R.D. dan Hadi, H. Pengaruh perubahan status gizi pasien dewasa terhadap lama rawat inap dan biaya rumah sakit. Jurnal Gizi Klinik Indonesia. 2004.
7. Consoli, M.L., Fonseca, L.M., Silver, R.G., \& Davisson, I.T. Early postoperative oral impact positively in patients undergoing colonic resection. Journal Nutrition Hospitalaria. 2010

8. Cameron, I.D. Kurrle, S.E., Lockwood, AU.L., \& Schaafsma, F.G. Effective of oral nutritional supplementation for older women after a fracture. Journal Biomed Central. 2011.

9. Syamsiatun, N.H., Hadi, H., Julia, M. Hubungan antar status gizi awal dengan status pulang dan lama rawat inap pasien dewasa. di rumah sakit. Jurnal Gizi Klinik Indonesia, 1 (1), pp. 27-33. 2004.

10. Nathens, A.B., Neff, M.J., Juurkovich G.J., Klot, Z.P., Farver, K. Ruzinski, J.T., Radella, F., Garcia, L., \& Maier, R.v. Randomized prospective trials of antioxidant supplementation in critically ill surgical patients, Journal Annals of Surgery vol 236. no, 6,9/4-822 pp 814. 2002.

11. Caccialanza, R., Klersy C., Cereda, E., Cameleti, B., Bonardi, A., Marinelli, M., \& Dionigi, P. Nutritional parameters associated with prolonged hospital stay among ambulatory adult patients, Journal CMAJ. 2010.

12. Shetty P.S dan James W.P.T. (1994)A measure of chronic energy deficiency in adults. FAO FOOD AND NUTRITION PAPER. Rome: FAO. 1994.

13. Kusumayanti, I.G.A., Hadi, H., Susetyowati. (2004) Faktor-faktor yang mempengaruhi kejadian malnutrisi pasien dewasa di ruang rawat inap. Jurnal Gizi Klinik Indonesia, 1 (1) Mei, pp. 9-17.

14. Departemen Kesehatan RI. (2005) Buku pedoman pelayanan gizi rumah sakit, Dirjen Pelayanan Medik, Direktorat Rumah Sakit Khusus Swasta, Jakarta.

15. Leandro, V.A., Aquino, B.D., (2010) Nutritional status and length of stay for surgical patients. Journal Nutrition Hospitalaria. 